\title{
Thematization Analysis on Basuki Tjahaya Purnama Staement on Surah al-Ma'ida 51
}

\author{
Aip Syaepul Uyun \\ Ma'soem University \\ *Corresponding Author \\ Email: aipsyaepul@masoemuniveristy.ac.id
}

\begin{abstract}
This paper aims to give a description on depth understanding of Surah Al-Ma'ida 51 and Ahok's statement analysis related to Surah Al-Ma'ida 51 which is believed that it had insulted Muslim community. The writer used thematisation context to analyze the data. It is done to find out the starting point of Ahok's utterances as the main key words of the base of the rest sentences. This theme can be inferred as an intention or motivation and also the purpose of the utterances. The writer analyzed the script of the video provided by the Jakarta Post published on Monday 10 Oktober 2016. Hence, after analyzing the syntactical form and also the theme of the utterances, it can be inferred that this statement does not consist any intention of insulting particular religion (Islam). It can be seen from the sentence starting point which is the residents of Thousand Islands and not Surat Al-Ma'ida.
\end{abstract}

Key words: Ahok, Statement, Thematization, Al-ma'ida-51,

\section{INTRODUCTION}

Referring to the tragedy on the 4th November and the 2nd December 2016 in Jakarta Indonesia, it had become major controversial issue among citizen in Indonesia, and being the most interesting topic where nearly all communities and social media were decorated with the issue. This tragedy had become the largest demonstration ever in Indonesian history and it was followed by more than one million people came down road and call it peaceful action It happened not only in Jakarta but also in many parts of Indonesia. This action campaigned against the governor of Jakarta, Basuki Tjahaya Purnama (Ahok) due to his statement on Surat Al-Ma'ida 51 (anti-Ahok).

This action was seen as endless. People followed Ahok trial to know the results of alleged Islamic blasphemy case. It even became the new phenomenon in which the coucil should be moved to a larger place due to too many visitors following the trial (3 January 2017). This situation had become the new tragedy in Indonesia after long life peaceful after the reformation era. This case rose such an issue disturbing Indonesia peaceful country with its slogan Bhineka Tunggal Ika (Unity in diversity).

The issue began when Basuki Tjahaya Purnama (Ahok) spoke in front of Thousand Islands residents in regards Jakarta administration officials about voting rights. He spoke about his future program and campaigned for the second election to be the governor of Jakarta. The most sensitive part came when He stated Surah AlMaidah 51, which caused many Muslims perceive as prohibiting them from voting for non-Muslim leaders (Ahok was the one of non-Muslim candidate) on the election. He spoke "you do not believe in people. In your hearts, ladies and gentlemen may not vote for me because [you have been] lied by Surah al-Maida, verse 51, etc. It is your right. So you do not need to feel uneasy if you cannot vote for me because you are afraid of being condemned to hell, as you are being fooled. It is alright" (Jakarta Post: 
Mon, October 10, 2016). As the result, this statement became the first reason on the tragedy of aksi damai (peaceful action) on the $4^{\text {th }}$ November and the 2 nd December 2016.

Ahok had apologized for the statement, which caused many Muslims found offensive. However, the majority Muslims still asked him sent into the legal process driven by Majelis Ulama Indonesia (Indonesian Council of Ulema). This was based on the consideration to what He stated regarding Surah Al-Maidah 51. MUI considered that the speech had insulted and offended Muslims community.

It did not take a long time after the tragedy, Ahok statement had generally assessed by many of us, scholars, politicians and even it became a booming discussion among academician in university. It came to the new case classifying public into two opinions. The first, majority Muslims assumed that the speech was considered to have an insult to particular religion and to offend Muslim community based on the nature of reference in text and discourse. Some scholars said Ahok had delivered a speech pitched insulting Muslim (Ariwanto: 2016) Indonesian Council of Ulema also did not miss their opinion against Ahok. Using their letter statement written on October $11^{\text {th }}$ 2016, they declared that Ahok statement was categorized insulting Quran and the Ulemas. On the other hand, Nusron Wahid (In Indonesian Lawyers Club: Tuesday October 11 th 2016) argued that Ahok utterances did not contain any intention of insulting Muslim community. He explained that there is none can analyze the intention of people speech. It is only the person speaking itself who knows what the exact meaning of its speech is. The same argument was also delivered by the great imam of Istiqlal Mosque of Jakarta, Nasaruddin Umar, he also stated that Ahok's statement about Al Maidah 51 was not categorized sacrilege. According to what he saw, it is not reflected in the sentence that Ahok had outraged the Quran (Makrum, 2019, p. 309).

Therefore, based on this case, the writer was interested in studying the issue. As a students of English Education Department UIN Syarif Hidayatulloh Jakarta, I learnt Linguistic and Islamic Studies. I also had a lot of discussion on how the case was lifted to the surface. Most refferences from article, research and book, supported by discussion, it had made a new different view toward the case. The question came, did Ahok really use the word to offend Muslim community? From this point, the writer was interested to analyze Ahok statement from linguistic perspective.

The researcher analyzed the statement using thematisation theory in linguistic aspect based on Haliday (1967). He said that each sentence has a theme (the starting point), and everything else that follows such as a ditails in the sentence, relates to the starting point of the utterance. The theme then is what speakers/writers use as what Halliday calls a 'point of departure' (Halliday, 1967: p. 212). The other authors, Brown and Yule explained that what comes first, as a theme or a topic, will influence the interpretation of everything that follows. They still argued that every clause, sentence and paragraph is organized in a written discourse around particular idea that is taken as its point of departure. It is Aknowledge by Mathesius (1942), he stated that we shall use term theme to refer to the formal category, the left-most constituent of sentence. Thus, theme in the clause or sentence has a significant position as the main part of the structure. In essence, the theme is the key word or main idea that will be discussed in a discourse. Furthermore, as we know that Halliday (1967) proposed three stages of thematisation. Namely declarative, interrogative and imperative sentences, In our discussion we shall focus on simple declarative sentences.

On the theoretical framework, the writer addressed the reader by providing the 
nature of Al-Ma'ida 51. It is very important to comprehend our understanding about the surah. Thus, from this understanding, we can continue to the issue related to Ahok's statement. This study is not to seek justification of Ahok's speech, or standing either to opposing or defending particular party, yet it is hoped this study can be used as reading material and a repertoire of science on the subject of both of Islamic studies and also linguistic. Here, it will started by the discussion of surah Al-ma'ida 51.

To start the analysis, it will be focused on the nature of Qur'anic meaning on Al-Ma'ida 51. Initially, the tragedy rose since Ahok stated the utterances related to surah Al-Ma'ida 51 which became the most sensitive part of his statement. He said that you do not believe in someone. In your hearts, ladies and gentlemen may not vote for me because [you have been] lied by Surah al-Maidah, verse 51, etc. It is your right. So you do not need to feel uneasy if you cannot vote for me because you are afraid of being condemned to hell, as you are being fooled. It is alright. The most sensitive part when He plastered Al-Maida 51. He said, you have been lied by Al-Maida 51.

Obviously, there are a lot of interpretations regarding the surah, what we will discuss here is about the most important part of the verse 5:51 which is the word Awliya. The qur'anic prescription to not take Jews and Christian as Awliya. This is one of the most controversial Qur'anic verse with regard to normative religious pluralism (Kemil, 2014). In order to enrich more scientific resources, we will discuss Al-ma'ida 51 from many different angles and perspectives of many scholars. Let us take a look at to the translation of Al-Maida 51.

O you who have believed, do not take the Jews and the Christians as allies. They are [in fact] allies one to another. And whoever is an ally to them among you - then indeed, he is [one] of them. Indeed, Allah does not guide the wrong doing people (Quran Alma'ida: 51).

Textually, this surah commands the Muslim not to take Jews and Christian as allies or protector. Interestingly, the word allies (awliya in the Koran) has a lot of meaning. However many Indonesian scholars translate it into the word leader. According to Sayyid Qutb fi Tafsir Zhilal in Irfannudin (2018, p. 217) explained that the word awliya has various meanings, not always be interpretated into the word leader. It depends on what context and when the verse was revealed. In more specific, he argued that the word awliya, First, this word is translated to the word help or guide. It is related to Jews, Christians and Kafirs, by making them the instructor of the Muslim way of life. Second, the word awliya is interpretated to the word guide, to guide, and protect. This meaning is linked into way in connection with God. Third, it means that believers who are truly devoted to Allah and always call for goodness and prevent Evil. In this context awliya is related to Satan making him as awliya.

On the other hand, Syamsuddin in Kemil (2014), he informed that many scholars particularly in Indonesia, they normally translate the word Awliya to the word Leaders. It can be seen in Tafseer al-Azhar written by Hamka for instance. Having the same meaning is also found in Tafseer Al-Maraby, Tafseer Ibnu Katseer and Tafseer alQurtuby. However, still, another book written by other scholars for example Muhammad ibn Jarir al-Tabari, he interpreted the word awliya to the word Ansar wa hulafa' which means (helper, aliance, and also friends). It also can be found on Tafseer Al-Misbah written by Quraish (Habibi, 2019, p. 18).

In the work of Kemil (2014), Ibnu Faris introduced one of the earliest semantic analysis related. He argued that the word Awliya came from the root morpheme waw- 
lam-ya, from which the word awliya is driven. It means a person in charge of other persons. In this case the English closest meaning to the word Awliya is 'guardian' (it is in line with Quraish Shihab meaning). He also gave another root of the word Awliya which come from the word lam-ya which is mawla. Those words gave another definition that mawla means "a slave who was set free, a person who freed a slave, a friend, a cousin, protector, and a neighbor".

Although there are so many definition of the word awliya, most exegetes interpret that Muslims are not permitted to show any affection toward religiously different people. Even further, Al-Zamakshshari and Al-Razi misconstrue to driven an understanding and requiring Muslim to isolate themselves from religiously different people and ignore them. It is also extremely dangerous if it is noted by westren countries and being known by any other religion. It can cause perception and interpretation that Islam does not give much support to acomodate normative religious pluralism (Habibi, 2019, p. 18).

Meanwhile, regardless the issue of its translation to the word awliya, this Surah also does not definitely qat'i respectively define the word. Therefore, inacurate translation of the word awliya has triggered and exacerbated controversy among Ulemas. Kemil (2014) argued that it is complex and ambiguous term, that the word appears in the verse as an accusative masculine plural noun in an indefinite grammatical form, and this later not being limited to any indicative description, and increase its complexity and ambiguity.

Therefore, semantic analysis of the concept of awliya reveals complex. It actually does not only consist of one definite meaning to the word leader, but also supporting another closest meaning related. That is why we need to observe this verse 51 from many angles of religious believe system. However, even so, we can also see that the word awliya can have various meanings such as a friend, a brother, a servant, a cousin, a teacher, or even a protector. It all depend on the historical context of the surah itself.

Refering to its historical context of Al-Ma'ida 51, it is not excessive that there are also many resources in regard the explanation of it. It is El Bajari, as quoted by Kemil (2014) had proposed three situations regarding the historical context of this surah. The first, it was when Mohammad's friend was going to ask for help from Jews and Christian to go for war because Muslim had not strong enough power at the time, then this verse came. Another argument stated that this surah came to Abdulloh bin Ubay bin Salul. He is the leader of Muslim enemy who is going to fight for a Muslim. This happens when Muslims were weak. so that many of them were afraid and asked for help from Jews and Christians. The third, this surah also sometimes is associated to Aisyah Radiyalloh Anha. She said once there is Christian offering Mohammad a help to war, yet Mohammad rejected him.

Another story about this surah, is that when Muhammad moved to Medina. He made an agreement stating that Muslims would not go to war with Jews and Christians. the Muslims who came to Medina at that time were in a difficult economic situation. until it came to the victory of the Badr war which caused the Muslim community became stronger in all aspects. Some of the idolaters allied and tricked them into converting to Islam just because they wanted the benefit from the victory of Muslims in the war of badr and not convert to Islam on the basis of faith. Prophet Muhammad saw this conspiracy, the agreement between them was canceled and there was no more alliance between them. (Habibi, 2019, p. 21)

On the other hand, regardless from the difference of many perspective toward 
the Asbabunnuju or Cronologycal history of this verse 5:51. It must be realized that understanding the Koran, it also needs to be understood as the whole context of the descent of the Koran. When the Koran was revealed, it was not empty, but it was a respond of particular situation happend. So, it will be tied to the situation and conditions at that time, whether it is from a cultural, political, economic and social perspective (Habibi, 2019, p. 21).

To infer the argument, it can be said that history showed the reasons for the prohibition to remind Muslims in times of conflict between religions. The scope of the prohibition is only for those who are between Jews and Christians trying to harass Muslims in matters of faith or involve them in a religious conflict. Therefore, this verse does not mean that Muslims should isolate themselves from Jews and Christians. This is because it was also proven by the prophet himself. After the conflict, he was still on good terms with the Banu Qoinuqo Jews in particular, and all Jews and Christians in general.

\section{METHOD}

The method of this research was qualitative descriptive. It provides descriptive analysis and focus on contemporary phenomenon within a real-life context and it was also focused on qualities of human behaviour (Yin, 2009, p. 2). The researcher has taken a lof of action and deeply analyzes the discourse. This process is conducted to understand and to explore the data. At this stage, the researcher has explored and analyzed the data of Critical Discourse Analysis using theroy from Haliday (1967) on the theory of thematization in linguistic.

The source of the data of this research is the textual transcript of Basuki Tjahaya Purnama (Ahok) when he spoke in front of Thousand Islands residents in regards Jakarta administration officials about voting rights. He spoke about his future program and campaigned for the second election to be the governor of jakarta. The most sensitive part came when He stated Surah Al-ma'ida 51, which cause many Muslims perceive as prohibiting them from voting for non-Muslim leaders. The script and the video of the data is taken from the official website of the Jakarta Post published on Mon, October 10, 2016. The data of this research are in the form of clauses, phrases and sentences that uttered by Ahok in the transcript of the speeches. The researcher uses one context in the text which became the most sensitive part of his statement. It is to explore the linguistics features though thematization analysis.

\section{FINDINGS AND DISCUSSION}

To start the analysis, it is very important that to aknowledge that language will have an ideology that is often missed by both writer/speaker as well as reader/hearer. Then persons are inadvertenly inspired by ideology camuflage in language (Widianingsih; 2021). That is why miss interpretation happend regarding the statement of Ahok had come to a various meaning. Then first, we must reallized that this is something normal. Thus everyone can respond it wisely.

Regarding the statement, the writer uses staging point or thematization in language as the theory of analysis. Brown and Yule (1983) explained that what comes first, as a theme or a topic, influences the interpretation of everything that follows. They still argued that every clause, sentence and paragraph is organized in a written discourse around particular idea that is taken as its point of departure. It is acknoledged by Mathesius (1942), he stated that we shall use term theme to refer to the formal category, the left-most constituent of sentence. It is because each sentence has a theme 
(the starting point of the utterance), and the sentences that follows such as a details in the sentence, relates to the starting point of the utterance. The theme then is what speakers/writers use as what Halliday calls a "point of departure" (Halliday, 1967, p. 212). Thus, theme in the clause or sentence has a significant position as the main part of the structure. In essence, the theme is the key word or main idea that will be discussed in a discourse. Halliday (1967) also proposed three stages of thematisation, namely declarative, interrogative and imperrative sentence. In our discussion we shall focus on simple declarative sentences and consider their thematic.

In order to study the discourse. It is necessary to know exactly the context of the situation. It is begun when Basuki Tjahaya Purnama (Ahok) spoke in front of Thousand Islands residents in regards Jakarta administration officials about voting rights. He spoke about his future program and campaigned for the second election to be the governor of Jakarta. The most sensitive part came when He stated Surah AlMaida 51, which cause many Muslims perceive as prohibiting them from voting for non-Muslim leaders. Here are his words,

So you don't believe in people, it could be that in your hearts, ladies and gentlemen may not vote for me because [you have been] lied by Surah al-Maidah, verse 51, etc. It is your right. So you do not need to feel uneasy if you cannot vote for me because you are afraid of being condemned to hell, as you are being fooled. It is alright," (Jakarta Post:

\begin{tabular}{|l|l|}
\hline Sentence & Result of analysis \\
\hline So, you do not believe in someone & $\begin{array}{l}\text { you is the subject of this sentence. So } \\
\text { this word (you) is the theme of the } \\
\text { sentence which are the resident of } \\
\text { Thousand Islands See Halliday } \\
(1957)\end{array}$ \\
\hline $\begin{array}{l}\text { It could be in your heart, Ladies } \\
\text { and gentlemen, you may not vote } \\
\text { for me, because you have been lied } \\
\text { by surah Al-Maida 51 }\end{array}$ & $\begin{array}{l}\text { in this sentence, the main topic } \\
\text { discussed is still "you" the residents of } \\
\text { Thousand Island }\end{array}$ \\
\hline $\begin{array}{l}\text { It is your right } \\
\text { So you do not need to feel uneasy if } \\
\text { you cannot vote for me because you } \\
\text { are afraid of being condemned to } \\
\text { hell, as you are being fooled }\end{array}$ & $\begin{array}{l}\text { The pronoun "you" refers to the } \\
\text { residents } \\
\text { become the main topic of the } \\
\text { discussion }\end{array}$ \\
\hline It is alright & This sentence is a closing statement \\
\hline
\end{tabular}

Mon, October 10, 2016).

Therefore, refering to its context, the theme of this sentence is clear. It is the residents of Thousand Island. Thus, the main topic discussed in the discourse is the people in the assembly. Take a look at to these following sentences.

According to Halliday, theme is also called a point of departure. It is the leftmost constituent in the sentence. The word which is put in this position functioned as 
subject which become the main topic to discuss in a sentence or utterance. Therefore, it is clear the staging point or the theme of these utterances is the residents of Thousand Islands. it can be seen from the table above. It provides a segmentation of the utterances. There are five sentences and each sentence has its own subject. However, take a look at to the first sentence which is the main idea of this text, the subject of the first sentence is the word you. It cannot be justified that the word you into particular person because it is too bias. Yet if we refer to the context of the discourse. Ahok actually delivered the speech to the Recidence of Thousand Islands. Hence, it can be infered that the theme of this utterence is the Recidence of Thousand Islands.

On the other hand, beyond this theory, we will be tied by the reality. It is when the speaker produce utterances, it normally would have different assumptions going to the hearer due to the different knowledge. It is called hearer's presuppositions (Brown and Yule, 1983). It is also what was happening to the two groups which agains nor stand for Ahok. We have known that the left-most constituent in the sentence is the subject of the declarative sentence. In fact, theory is just merely theory. Reality and generality in society become stronger opinion when it come to the tragedy.

Another issue regarding the utterances is about about Surah Al-Maida 51, which caused many Muslims think that he had insulted Islam for saying that you have been lied by Al-maida 51. In general, this sentence have many meanings. There e those who interpret that Ahok said Al-maida 51 is a lie, or there are also those who say that people is being lied by Al-maida 51. or maybe there are also people who say the residence is lied by people using Al-maida 51.

By the end, a lot of interpretation come for only one sentence. It is because people have different knowledge and also understanding through the topic. They will only interprent the language based on their prior knowledge without analysing it first. if we analyse the sentece only. It is yes possible we find a tyfically exact the same interpretation. However we need to realize, in order to analyse discourse, it is very important that we have to bring all sentences or utterances combining together in to the context. Here we can see from the analysis.

Another part which is very essential to discuss is about the type of sentence itself. Here in this utterances, Ahok used passive form. People might not find such an obstacle to analyze the form of active sentence, yet if it is constructed in passive, the story is different. this also results many interpretations toward the sentence.

Now, take a look again at to this discourse stated by Ahok on the election. He spoke

So don't believe in people, it could be that in your hearts, ladies and gentlemen may not vote for me because [you have been] lied by Surah al-Maidah, verse 51, etc. It is your right. So you do not need to feel uneasy if you cannot vote for me because you are afraid of being condemned to hell, as you are being fooled. It is alright," (Jakarta Post: Mon, October 10, 2016).

The most sensitive part of the utteance, is about the word you have been lied by Al Maida 51. It is mostly impossible to analyze the sentence without combining all together into one context. So we need to make sure that we also bring all sentences into one discourse. Then we can start analysis. If we refer to the sentence, this words belong to the second sentence. and back into the first one, it can be seen that the sentence ommited the object and went directly to the adverb. In fact if we analyse 
it more, it probably that there is an object of the sentence (So you do not believe in people) the word people is probably the object of the sentence which will become agent of the verb lie. Hence if we must break it down, it can be like this

So you do not believe in people (you is the subject of this sentence. People is the object of the sentence)

It could be in your heart, Ladies and gentlemen (you) may not vote for me Because you have been lied by someone using surah Al-maida verse 51 and ect

So, in this sentence, Al-maida 51 is not a main part of the discussion. Because its position is an adverb.

Since Ahok statement was stated in passive form, then it is continued more to discuss the passive form on the sentence. According to Claiman (1991) in Allan (2009) he argued that in flexion language like Latin, Greek, Sanskrit, even Semitic languages such as English and Arabic, there are forms of verb called active and passive. It can be confirmed from the usage of the verb itself. It refers to the active form when the subject embodied in the form of the verb and it becomes agent. Instead, a form of the verb refers to the passive form when the subject contained in the verb form it into object (Gopen, 2014). Thus, it appears that the notions of active and passive flexion in these languages should be viewed by the unitary form of the verb with the subject.

In the Indonesian concept of active and passive sentences, it can be seen from a different perspective. One of the concepts is driven from the traditional view. While the concept is based on the view that both transformative grammars. The first is using the passive voice. The emphasis in the form of the passive voice is formed with a view to further confirm the role of the patient objects (Gopen: 2014). Other concept would be driven from the perspective of pragmatic which will be analyzed not only related to the grammatical construction of the sentence, but also the language usage of it.

In order to recognise more about indonesian passive structure, we can read Supranto (2012, p. 290). He clearly informed that Passive sentences in Indonesian are seen from the structure using di-ter-ke- (this is a kind of prefix in Indonesian) which in English only recognizes to be + past participle and depends on the time of the incident refferes to the tenses). Passive sentences in Indonesian are formed by adding the prefix of the word ter- and $d i$-. It will provide other meanings and interpretations to the meaning of the sentences made. Passive sentences using prefix $d i$-, shows an element of spelling to emphasize the object of a passive sentence, for example I was trown by someone in the bus. This sentence means that someone deliberately throws the object outside the bus. It means this actions was done purposely. On the other hand, if the sentence using prefix ter-, it means the action was done unpurposely.

In relation to Ahok statement, he use his statement using prefix $d i-$, it means there is an intention which is purposely to say that many people have been lied by Al-Maidah 51. Theoritically, according to Indonesian structure of passive form, if the sentence using the prefix $d i$-, it means that the action is purposely done by someone. As the result, there must be someone as an agent for doing the action. Here take a look at to this table. 
Journal of English Teaching Adi Buana, Vol. 06 No. 01, April 2021

\begin{tabular}{|l|l|}
\hline Without agent & With agent (hidden) \\
\hline You- subject & You- subject \\
Have been lied - verb & Have been lied - verb \\
By Al-Maidah 51-Adverb & By Al-Maidah 51-Adverb \\
& Hidden agent - someone using Al-Maidah \\
\hline
\end{tabular}

The table above provides a brief overview of the probability of the sentece. From the talbe, we know that the original sentence which is without agent. He hide the agent of the sentence. There are reasons for this, one of them He used many considerations that mentioning the agent will be inappropriate causing the embarrassment or impolite (Sinha, 1974). So, it is normal that agents or subjects in passive sentences are often omitted (Gopen, 2014). Further, in the work of Allan (2009) Granger (1983) observes that in English there is a lack of suitable personal pronoun when there is no need to say who is doing something, which leads to choosing the passive form, as in general preference. Stanley and Robbins (1977) observe that the reader may identify in all these truncated passives, there are sound reasons for omitting the agent, that is, the use of the passive construction is appropriate. In Relational Grammar terms, the agents are clearly hidden, they are unemployed. As the result Ahok implied that the agent was actually the person who use that way (Surah al-Maidah, verse 51 to lie the people).

Therefore, it comes to the conclusion which I personally believe that the statement does not consist the intension of insulting Muslim community by stating that the surah $\mathrm{Al}$ maida 51 has lied people in Thousand Islands. It can be seen from the syntactical form of the sentence. He did not say that Surat Al-ma'ida is fictive, yet he said that the people have been lied by someone using surah Al-ma'ida. Meaning he said to the people to not believe to someone laying them using the surah. It is like what we have discussed before, the sentence did not consist of an agent (who is doing it) and the agent of this sentence is someone using Surat Al-ma'ida.

\section{CONCLUSION}

Something is more saddening is that particular groups were pushing the government to immediately threw Ahok into prison while the legal process was running. The groups were insisting that the literal out-of-context interpretation of al-Maida 51 is the only correct one. They took for granted that the verse literally prohibits non-Muslims from being a "leader" in a Muslim country. However, in reality the word Awliya is not always be translated into the word leader. The verse will only make sense if understood in its context, that is, in a situation of war, such as when the Jews were said to have betrayed the Muslims by violating the social contract made between the two to defend Medina together when the city-state was under attack.

Regarding the statement, as the writer said before, it is believed that the sentence did not consist of the intention of insulting particular religion. It can be proven from the thematisation analysis provided in the work of Brown and Yule (1988). It is said that the starting point of this sentence is not the Surah Al-Maida 51, but the residents whom being asked to not believe in someone using this surah to lie them. It can be analyzed from the whole sentences taken from the video which is the starting from the utterances "you do not believe to someone". Surah Al-maida in this case is an adverb 
of these sentences which is neutral. However, even if I personally can say that the sentence was not categorize insulting Islam, as Muslims, I still felt hurt by his words. It is such inappropriate sentence uttered by public figure.

\section{REFERENCES}

Allan, Stu. (2009). Passive construction. Cattenbury. University of Cattenbury. New Zeland.

Aslan, Adnan. (2020). Religious Pluralism in Islam. Journal of Islamic Thought and Civilization. Vol 1, Issues 1.

Basya, Hilaly. (2011). The Concept of Religious Pluralism in Indonesia. Department of Religious Study at the University of Leeds UK. Vol 1. No 1.

Beuhler, Michel. (2009). Islam and Democracy in Indonesia. Insigt Turkey. Turkey.

Brown, G. \& Yule, G. (1983). Discourse Analysis. Cambridge: CUP.

Efley, Jenifer. (2010). Religion and Politic and Contemporary Indonesia. The University of Michiggan. USA.

Fuad, Zainul. (2007). Religious Pluralism in Indonesia. University of Humberg. Jermani

Hadiz, Vedi. (2010) Islam in post Autoritarian Indonesia. Univerity of Oxford. United Kingdom

Halliday, M. A. K. (1985). An Introduction to Functional Grammar. London.

Halliday, M. A. K. (1967). Notes on transitivity and theme in English: part 2' Journal of Linguistics Vol 3, p. 199-244.

Hamayotsu, Kikue. (2015). Democracy and Religious Pluralism in Southeast Asia. Northem Illinois University. USA

Hasyim, Kamaly.(2012). Diversity and Religious Pluralism from Qur'anic Perspective. International Institute of Advanced Islamic Studies. Malaysia.

Imron, Mohammad. (2013). Religious Pluralism. Center Punjab University Lahore. Pakistan.

Infanuddin, M. (2018). Auliya in da fi Sayid Quthb Fi Tafsir Zhial. Gontor Darussalam University. Indonesia.

Kemil, Arif. (2014). Qur'an and Normative Religious Pluralism. Gutember press. Malta.

McKim, Roberth. (2010). Religious Pluralism. Journal of College and Character. Vol 11, No 2, May 2010.

Mathesius, V. (1942). 'From comparative word order studies' Casopis pro Moderni Filoligii 28.

Levelt, W. J. M. (1981). 'The speaker's linearisation problem' in The Psychological Mechanism of Language. The Royal Society and The British Academy.

Safiq, Hasyim. (2013). Considering Indonesian Islam as a Model of Democracy in the world. Liberal Institute. Berlin.

Van Dijk, T.A. (1977) Text and Context, London: Longman.

KBR Jakarta. Thursday October $1^{\text {st }}$ 2016. Imam besar Masjid Istiqlal: Perkataan Ahok Tidak Menistakan Agama

Profesionalisme Guru.com Thursday October $1^{\text {st }}$ 2016. Analisis Perkataan Ahok.

Widianingsih. (2021). The Ideology of President Joko Wiodo Through His Inaguration Speech. Journal of English Paedagogy and Applied Linguistics. Vol 1. No 2 